\title{
EXCAVATIONS AT MA'LAYBA AND SABIR, REPUBLIC OF YEMEN: RADIOCARBON DATINGS IN THE PERIOD 1900 TO 800 CAL BC
}

\author{
Jochen Görsdorf ${ }^{1}$ Burkhardt Vogt ${ }^{2}$ \\ ABSTRACT. The Bronze and Iron Age cultures in Yemen have no parallels to the well dated cultures in the Syro-Palestinian \\ region. Radiocarbon datings are therefore exceptionally important for the Yemenite archaeological excavation sites of \\ Ma'layba and Sabir, the latter being the largest excavation site of the Sabir culture. Dating series were done in order to deter- \\ mine the architectural development of the sites and find time marks for the ceramic development. Sample materials were dated \\ from the 2 nd and 1 st millennium before Christ. The ${ }^{14} \mathrm{C}$ dating results allow statements about the cultural development in \\ Ma'layba and Sabir as well as a comparison with the development of other regions in the surrounding, independent of only \\ sparse available archaeological parallels.
}

\section{INTRODUCTION}

Since 1994, the joint German-Russian expedition has provided evidence for a hitherto unknown preIslamic archaeological complex in the hinterland of Aden (Republic of Yemen). At present, this Sabir Culture appears restricted to the southern Saudi Tihama and to Yemen's coastal plains along the Red Sea and the western Gulf of Aden. During its later stages it overlaps chronologically with the much better known South Arabian Civilisation which starts to appear along the desert fringes of Ramlat as-Sab'atayn and the High Yemen as early as the 12th century BC. Cultural exchange between coast and interior appears limited and long distance relations with cultures beyond South West Arabia (Pre-Axumite North East Africa/Levante) cannot be used for the reconstruction of chronological framework.

The two most important stratified sites of the Sabir Culture are Ma'layba and Sabir in the Lahj Governorate (Figure 1). Partial congruencies of their inventories make them suitable for the definition of an emerging cultural sequence that can now be dated by 35 radiocarbon dates.

The settlement of Ma'layba is a relatively small tell at the southern edge of the al-Hawta/Lahj oasis some $20 \mathrm{~km}$ north of the port of Aden. In a deep sounding its total stratigraphic sequence with about $6 \mathrm{~m}$ of cultural layers could be studied. Anthropogenic deposits start almost immediately above two superimposed paleosols that elsewhere in Yemen are attributed to the 6th and the 4th millennia BC. Stratified dwelling architecture has survived only as posthole patterns and burnt pole remains of huts alternating with layers of agricultural fields and irrigation channels. Associated ceramics reflect the distinction of two major periods: a long and early period I divided into phases Ia through c, and a shorter period II after which the site was obviously abandoned.

\section{METHODS}

Chemical pretreatment of wood and charcoal samples was done by AAA treatment (Mook and Streurman 1983). The dating was performed with gas proportional counters of the HoutermansOeschger type, using methane at $133.3 \mathrm{kPa}$ pressure as filling gas. Measurement control and data processing were done using computers (Görsdorf 1990; Görsdorf and Bojadziev 1996). Since 1997 (Bln-4977), modern electronics have been used. The preamplifier, pulse amplifier, comparator,

\footnotetext{
${ }^{1}$ German Institute of Archaeology, Eurasian-Department, P.O. Box 3300 14, D-14191 Berlin, Germany. Corresponding author. Email: 14C@dainst.de.

${ }^{2}$ German Institute of Archaeology, Orient-Department, branch office Sanaa, c/o German Embassy, P.O. Box 2562, SanaaRepublic of Yemen
}

(C) 2001 by the Arizona Board of Regents on behalf of the University of Arizona Near East Chronology: Archaeology and Environment. RADIOCARBON, Vol 43, Nr 3, 2001, p 1353-1361

Proceedings of the 17 th International ${ }^{14} \mathrm{C}$ Conference, edited by $\mathrm{H} J$ Bruins, I Carmi, and E Boaretto 
pulse shaper, and anti-coincidence units are located in a box $(19 \mathrm{~cm} \times 10 \mathrm{~cm} \times 5 \mathrm{~cm})$, which is directly connected to the counter. The detection of variation of the environmental radiation and the inspection of the long time stability of the electronics were required in order to reach the measurement accuracy (Görsdorf 2000). The $\delta^{13} \mathrm{C}$ measurements were done at the Leibniz-Labor, University of Kiel, Germany and are reported in permil relative to PDB-standard.

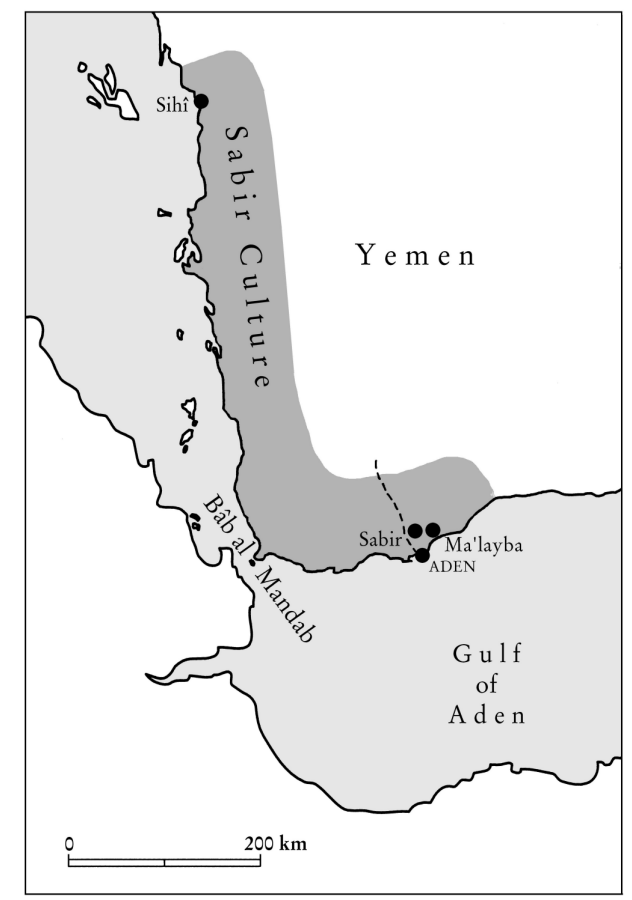

Figure 1 Map of the surroundings of Sabir and Ma'layba

\section{RESULTS}

The results with sample numbers, site names, and dating materials are shown in Tables 1 and 2 for Ma'layba and Sabir, respectively. We show the ${ }^{14} \mathrm{C}$ ages in BP, rounded off to the nearest 5. The datings are corrected for isotopic fractionation using the measured $\delta^{13} \mathrm{C}$ values. The ${ }^{14} \mathrm{C}$ ages are calibrated using the program OxCal v3.5 (Ramsey 1995, 2000) and employing the decadal calibration curve (Stuiver et al. 1998) as a first approximation for all samples. The tree ring count of the charcoal samples could not be determined. The calibration intervals were presented for a confidence of $68.2 \%$ and are rounded off to 10 years.

Table 1 Summary of dating results from Ma'layba and Sabir 2/2A

\begin{tabular}{|c|c|c|c|c|}
\hline $\begin{array}{l}\text { Lab no. } \\
\text { Sample } \\
\text { material }\end{array}$ & Sample number, Site name & $\delta^{13} \mathrm{C}(\% o)$ & ${ }^{14} \mathrm{C}$ age (BP) & $\begin{array}{c}\text { Calibrated range } \\
1 \sigma(68,2 \%)\end{array}$ \\
\hline $\begin{array}{l}\text { Bln-5148 } \\
\text { Charcoal }\end{array}$ & $\begin{array}{l}\text { Ma'layba II; ML97/1, trench extension, } \\
\text { Loc. } 1, \text { H. } 50.00 \text {, burnt wooden post }\end{array}$ & -25.3 & $3010 \pm 35$ & $\begin{array}{l}1370-1340 \mathrm{cal} \text { BC } \\
1320-1210 \mathrm{cal} \mathrm{BC} \\
1200-1190 \mathrm{cal} \text { BC } \\
1140-1130 \mathrm{cal} \text { BC }\end{array}$ \\
\hline
\end{tabular}


Table 1 Summary of dating results from Ma'layba and Sabir 2/2A (Continued)

\begin{tabular}{|c|c|c|c|c|}
\hline $\begin{array}{l}\text { Lab no. } \\
\text { Sample } \\
\text { material }\end{array}$ & Sample number, Site name & $\delta^{13} \mathrm{C}(\% o)$ & ${ }^{14} \mathrm{C}$ age (BP) & $\begin{array}{l}\text { Calibrated range } \\
1 \sigma(68,2 \%)\end{array}$ \\
\hline $\begin{array}{l}\text { Bln-5150 } \\
\text { Charcoal }\end{array}$ & $\begin{array}{l}\text { Ma'layba Ic; ML97/3, area H, } \\
\text { Loc. } 9 ; \text { H. } 48.90\end{array}$ & -26.1 & $3005 \pm 30$ & $\begin{array}{l}1370-1360 \mathrm{cal} \mathrm{BC} \\
1320-1210 \mathrm{cal} \mathrm{BC} \\
1200-1190 \mathrm{cal} \mathrm{BC} \\
1180-1160 \mathrm{cal} \mathrm{BC} \\
1140-1130 \mathrm{cal} \text { BC }\end{array}$ \\
\hline $\begin{array}{l}\text { Bln-5149 } \\
\text { Charcoal }\end{array}$ & $\begin{array}{l}\text { Ma'layba Ic; ML97/2, trench extension, } \\
\text { area D, Loc. 14; H. } 48.62\end{array}$ & -25.2 & $3305 \pm 35$ & $1620-1520 \mathrm{cal} \mathrm{BC}$ \\
\hline $\begin{array}{l}\text { Bln-5151 } \\
\text { Charcoal }\end{array}$ & $\begin{array}{l}\text { Ma'layba Ic; ML97/4, area I-J; } \\
\text { Loc. } 20 ; \text { H. } 48.25\end{array}$ & -25.5 & $3290 \pm 35$ & $1620-1520 \mathrm{cal} \mathrm{BC}$ \\
\hline $\begin{array}{l}\text { Bln-5152 } \\
\text { Charcoal }\end{array}$ & $\begin{array}{l}\text { Ma'layba Ic; ML97/5, trench extension, } \\
\text { area F; Loc. 22; H. } 47.98\end{array}$ & -26.6 & $3330 \pm 35$ & $\begin{array}{l}1690-1580 \mathrm{cal} \mathrm{BC} \\
1570-1520 \mathrm{cal} \mathrm{BC}\end{array}$ \\
\hline $\begin{array}{l}\text { Bln-5153 } \\
\text { Charcoal }\end{array}$ & $\begin{array}{l}\text { Ma'layba Ic; ML97/6, area H; } \\
\text { Loc. 56; H. } 47.52\end{array}$ & -26.2 & $3245 \pm 30$ & $\begin{array}{l}1600-1570 \text { cal BC } \\
1530-1440 \text { cal BC }\end{array}$ \\
\hline $\begin{array}{l}\text { Bln-5154 } \\
\text { Charcoal }\end{array}$ & $\begin{array}{l}\text { Ma'layba Ib; ML97/7, trench extension, } \\
\text { area D, Loc. 24; H. } 47.67 \text { / } 47.47 \text {, } \\
\text { burnt wooden post }\end{array}$ & -26.3 & $3405 \pm 35$ & $\begin{array}{l}1750-1680 \mathrm{cal} \mathrm{BC} \\
1670-1630 \mathrm{cal} \mathrm{BC}\end{array}$ \\
\hline $\begin{array}{l}\text { Bln-5155 } \\
\text { Charcoal }\end{array}$ & $\begin{array}{l}\text { Ma'layba Ia; ML97/8, trench extension, } \\
\text { area B; Loc. } 31 ; \text { H. } 47.16 \text { / } 46.96 \text {, } \\
\text { standing burnt wooden post }\end{array}$ & -26.1 & $3455 \pm 40$ & $\begin{array}{l}1880-1840 \mathrm{cal} \mathrm{BC} \\
1820-1790 \mathrm{cal} \mathrm{BC} \\
1780-1730 \mathrm{cal} \mathrm{BC} \\
1720-1690 \mathrm{cal} \mathrm{BC}\end{array}$ \\
\hline $\begin{array}{l}\text { Bln-5156 } \\
\text { Charcoal }\end{array}$ & $\begin{array}{l}\text { Ma'layba Ia; ML97/10, trench extension, } \\
\text { area B, Loc. 49; H. } 46.73 \text { / 46.47; } \\
\text { fireplace }\end{array}$ & -25.8 & $3550 \pm 35$ & $\begin{array}{l}1950-1870 \text { cal BC } \\
1850-1810 \text { cal BC } \\
1800-1770 \text { cal BC }\end{array}$ \\
\hline $\begin{array}{l}\text { Bln-4631 } \\
\text { Charcoal }\end{array}$ & $\begin{array}{l}\text { Sabir 2, pit 2; Sab93/3, mud brickwall, } \\
\text { in front of Loc. } 4\end{array}$ & -11.0 & $2845 \pm 40$ & $1050-920 \mathrm{cal}$ BC \\
\hline $\begin{array}{l}\text { Bln-4632 } \\
\text { Charcoal }\end{array}$ & $\begin{array}{l}\text { Sabir 2, pit 2; Sab93/4, upper ash-layer } \\
\text { in Loc. } 6\end{array}$ & -19.9 & $2910 \pm 40$ & $\begin{array}{l}1210-1200 \mathrm{cal} \mathrm{BC} \\
1190-1170 \mathrm{cal} \mathrm{BC} \\
1160-1140 \mathrm{cal} \mathrm{BC} \\
1130-1010 \mathrm{cal} \mathrm{BC}\end{array}$ \\
\hline $\begin{array}{l}\text { Bln-4633 } \\
\text { Charcoal }\end{array}$ & $\begin{array}{l}\text { Sabir 2, pit 2; Sab93/6, 3. ash-layer } \\
\text { in Loc. } 6\end{array}$ & & $3030 \pm 50$ & $\begin{array}{l}1390-1250 \mathrm{cal} \mathrm{BC} \\
1240-1210 \mathrm{cal} \mathrm{BC} \\
1200-1190 \mathrm{cal} \mathrm{BC} \\
1140-1130 \mathrm{cal} \mathrm{BC}\end{array}$ \\
\hline $\begin{array}{l}\text { Bln } 4630 \\
\text { Charcoal }\end{array}$ & Sabir 2A=Sabir 2, pit 1; Sab93/1, Loc. 1 & & $2820 \pm 60$ & $\begin{array}{r}1050-890 \mathrm{cal} \mathrm{BC} \\
880-860 \mathrm{cal} \mathrm{BC}\end{array}$ \\
\hline
\end{tabular}


Table 1 Summary of dating results from Ma'layba and Sabir 2/2A (Continued)

\begin{tabular}{|c|c|c|c|c|}
\hline $\begin{array}{l}\text { Lab no. } \\
\text { Sample } \\
\text { material }\end{array}$ & Sample number, Site name & $\delta^{13} \mathrm{C}(\% \circ)$ & ${ }^{14} \mathrm{C}$ age (BP) & $\begin{array}{c}\text { Calibrated range } \\
1 \sigma(68,2 \%)\end{array}$ \\
\hline $\begin{array}{l}\text { Bln } 4883 \\
\text { Charcoal }\end{array}$ & Sabir 2A; Sab95/1, Loc. 3 & -15.0 & $2765 \pm 40$ & $\begin{array}{l}970-950 \mathrm{cal} \mathrm{BC} \\
930-890 \mathrm{cal} \mathrm{BC} \\
880-830 \mathrm{cal} \mathrm{BC}\end{array}$ \\
\hline $\begin{array}{l}\text { Bln } 4884 \\
\text { Charcoal }\end{array}$ & Sabir 2A; Sab95/2, Loc. 18 & -25.8 & $2730 \pm 35$ & $900-830$ cal BC \\
\hline $\begin{array}{l}\text { Bln } 4885 \\
\text { Charcoal }\end{array}$ & Sabir 2A; Sab95/3, Loc. 22 & -26.0 & $2835 \pm 40$ & $1050-920 \mathrm{cal} \mathrm{BC}$ \\
\hline $\begin{array}{l}\text { Bln } 4886 \\
\text { Charcoal }\end{array}$ & Sabir 2A; Sab95/4, Loc. 33 & -26.8 & $2840 \pm 30$ & $\begin{array}{l}1040-1030 \mathrm{cal} \mathrm{BC} \\
1020-920 \mathrm{cal} \mathrm{BC}\end{array}$ \\
\hline $\begin{array}{l}\text { Bln } 4887 \\
\text { Charcoal }\end{array}$ & Sabir 2A; Sab95/5, Loc. 42 & -24.9 & $2875 \pm 35$ & $1130-990 \mathrm{cal} \mathrm{BC}$ \\
\hline
\end{tabular}

Table 2 Summary of dating results from Sabir 5 (building 1, 2, 3) and Sabir 8A

\begin{tabular}{|c|c|c|c|c|}
\hline $\begin{array}{l}\text { Lab no., } \\
\text { Sample } \\
\text { material, } \\
\text { Site }\end{array}$ & Sample number, Location & $\delta^{13} \mathrm{C}(\% o)$ & ${ }^{14} \mathrm{C}$ age (BP) & $\begin{array}{l}\text { Calibrated range } \\
1 \sigma(68,2 \%)\end{array}$ \\
\hline $\begin{array}{l}\text { Bln-4727 } \\
\text { Charcoal } \\
\text { Sabir } 5\end{array}$ & $\begin{array}{l}\text { Sab94/95-1, building } 2 \text {, kitchen area, fireplace with } \\
\text { pot V1 in room 1, on the uppermost floor, Loc. } 3 \text {, } \\
\text { H. } 49.94\end{array}$ & & $2775 \pm 45$ & $\begin{array}{l}980-890 \text { cal BC } \\
880-830 \text { cal BC }\end{array}$ \\
\hline $\begin{array}{l}\text { Bln-4728 } \\
\text { Charcoal } \\
\text { Sabir } 5\end{array}$ & $\begin{array}{l}\text { Sab94/95-2, building } 2 \text {, kitchen area, NE-corner of } \\
\text { the room 1, layer above uppermost floor, H. } 50.12\end{array}$ & -25.4 & $2885 \pm 35$ & $\begin{array}{l}1130-1000 \quad \mathrm{cal} \\
\mathrm{BC}\end{array}$ \\
\hline $\begin{array}{l}\text { Bln-4729 } \\
\text { Charcoal } \\
\text { Sabir } 5\end{array}$ & $\begin{array}{l}\text { Sab94/95-3, building } 2 \text {, kitchen area, fireplace in } \\
\text { passage between rooms } 1 \text { and } 2 \text {, layer above } \\
\text { uppermost floor, H. 50.11, Loc. } 3-4\end{array}$ & -16.1 & $2775 \pm 40$ & $\begin{array}{l}980-950 \text { cal BC } \\
940-890 \text { cal BC } \\
880-830 \text { calBC }\end{array}$ \\
\hline $\begin{array}{l}\text { Bln-4730 } \\
\text { Charcoal } \\
\text { Sabir } 5\end{array}$ & $\begin{array}{l}\text { Sab94/95-4, building 1, courtyard, layer above } \\
\text { uppermost floor, Loc. } 18, \text { H. } 50.03\end{array}$ & -25.9 & $2840 \pm 40$ & $1050-920 \mathrm{cal} \mathrm{BC}$ \\
\hline $\begin{array}{l}\text { Bln-4731 } \\
\text { Charcoal } \\
\text { Sabir } 5\end{array}$ & $\begin{array}{l}\text { Sab94/95-5, building } 2 \text {, kitchen area, room } 1 \text {, } \\
\text { above lower floor, Loc. } 46\end{array}$ & -26.2 & $2695 \pm 40$ & $\begin{array}{l}900-870 \mathrm{cal} \mathrm{BC} \\
860-800 \mathrm{cal} \mathrm{BC}\end{array}$ \\
\hline $\begin{array}{l}\text { Bln-4888 } \\
\text { Charcoal } \\
\text { Sabir } 5\end{array}$ & $\begin{array}{l}\text { Sab95/6, building 2, courtyard, layer above lowest } \\
\text { settlement horizon, earliest settlement of } 5 \mathrm{~A} \text {, Loc. } \\
52\end{array}$ & -25.9 & $2965 \pm 35$ & $1260-1120 \mathrm{cal} \mathrm{BC}$ \\
\hline $\begin{array}{l}\text { Bln-4889 } \\
\text { Charcoal } \\
\text { Sabir } 5\end{array}$ & $\begin{array}{l}\text { Sab95/7, building } 3 \text {, uppermost layer, destruction } \\
\text { of building } 3 \text {, H. } 48.93\end{array}$ & -26.0 & $2785 \pm 40$ & $\begin{array}{r}1000-890 \mathrm{cal} \mathrm{BC} \\
880-860 \mathrm{cal} \mathrm{BC} \\
850-840 \mathrm{cal} \mathrm{BC}\end{array}$ \\
\hline
\end{tabular}


Table 2 Summary of dating results from Sabir 5 (building 1,2,3) and Sabir 8A (Continued)

\begin{tabular}{|c|c|c|c|c|}
\hline $\begin{array}{l}\text { Lab no., } \\
\text { Sample } \\
\text { material, } \\
\text { Site }\end{array}$ & Sample number, Location & $\delta^{13} \mathrm{C}(\% \circ)$ & ${ }^{14} \mathrm{C}$ age (BP) & $\begin{array}{l}\text { Calibrated range } \\
1 \sigma(68,2 \%)\end{array}$ \\
\hline $\begin{array}{l}\text { Bln-4890 } \\
\text { Charcoal } \\
\text { Sabir } 5\end{array}$ & $\begin{array}{l}\text { Sab95/8, building 3, room 3, Loc. 5/Loc. 14, H. } \\
49.10 \text {, dating of skeleton and destruction of } \\
\text { building } 3\end{array}$ & -23.9 & $2815 \pm 40$ & $1010-900 \mathrm{cal} \mathrm{BC}$ \\
\hline $\begin{array}{l}\text { Bln-4891 } \\
\text { Charcoal } \\
\text { Sabir } 5\end{array}$ & $\begin{array}{l}\text { Sab95/9, building } 3 \text {, Loc. } 4 \text {, vessel contents of } \\
\text { V41, H. ca. } 48.80 \text {, dating of the destruction of the } \\
\text { deposit }\end{array}$ & -25.8 & $2760 \pm 35$ & $\begin{array}{l}970-960 \text { cal BC } \\
930-890 \text { cal BC } \\
880-830 \text { cal BC }\end{array}$ \\
\hline $\begin{array}{l}\text { Bln-5093 } \\
\text { Charcoal } \\
\text { Sabir } 5\end{array}$ & $\begin{array}{l}\text { Sab96-1, Sabir } 5 \text { c, east of room } 5 \text {, } \\
\text { Loc. } 53\end{array}$ & -24.5 & $2905 \pm 35$ & $\begin{array}{l}1190-1180 \mathrm{cal} \mathrm{BC} \\
1150-1140 \mathrm{cal} \mathrm{BC} \\
1130-1010 \mathrm{cal} \mathrm{BC}\end{array}$ \\
\hline $\begin{array}{l}\text { Bln-4892 } \\
\text { Charcoal } \\
\text { Sabir 8A }\end{array}$ & Sab94/11, Loc. 4 extension, ca. H. 46.70 & -25.6 & $2840 \pm 35$ & $1050-920 \mathrm{cal} \mathrm{BC}$ \\
\hline $\begin{array}{l}\text { Bln-4893 } \\
\text { Charcoal } \\
\text { Sabir 8A }\end{array}$ & Sab94/12, Loc. 6 East-extension, H. 46.22 & -23.8 & $2835 \pm 30$ & $1020-920 \mathrm{cal} \mathrm{BC}$ \\
\hline $\begin{array}{l}\text { Bln-4894 } \\
\text { Charcoal } \\
\text { Sabir 8A }\end{array}$ & $\begin{array}{l}\text { Sab94/13, Loc. } 9 \text { A, beginning of the } \\
\text { pottery sequence under the building, } \\
\text { ca. } 1 \mathrm{~m} \text { under the surface }\end{array}$ & -25.2 & $2965 \pm 35$ & $1260-1120 \mathrm{cal} \mathrm{BC}$ \\
\hline $\begin{array}{l}\text { Bln } 4895 \\
\text { Charcoal } \\
\text { Sabir 8A }\end{array}$ & Sab94/14, Loc. 9B, H. 46.21 & -24.4 & $2885 \pm 40$ & $\begin{array}{l}1190-1180 \mathrm{cal} \mathrm{BC} \\
1130-1000 \mathrm{cal} \mathrm{BC}\end{array}$ \\
\hline $\begin{array}{l}\text { Bln-4896 } \\
\text { Charcoal } \\
\text { Sabir 8A }\end{array}$ & Sab94/15, Loc. 9C, H. 45.52 & -24.9 & $2975 \pm 40$ & $\begin{array}{l}1290-1280 \mathrm{cal} \mathrm{BC} \\
1270-1120 \mathrm{cal} \mathrm{BC}\end{array}$ \\
\hline
\end{tabular}

\section{DISCUSSION}

The calibrated dates from Ma'layba seem reliable. Thus, the series dates an early phase of the coastal culture-more precisely the seven centuries before the main occupation of the key and type site Sabir. The stratigraphic distinction of two major occupations at Ma'layba is confirmed, and moreover, the parallel ceramic development mainly during period I is corroborated.

Almost all samples relate to period I and to its phases a-c assigning them to the 20th to 13th century $\mathrm{BC}^{3}$. Period Ma' layba II, represented solely by sample Bln-5148, starts during the 14th/13th century $\mathrm{BC}-\mathrm{a}$ time when Ma'layba pottery was completely identical to productions from Sabir. Regarding the stratigraphically older sample Bln-5150 and its associated period Ic pottery, it is highly likely that the dividing line between the two periods needs to be drawn right through the 13th century BC.

${ }^{3}$ Note that the stratigraphically earliest sample has not yet been submitted for AMS dating but a late 3rd mill. BC date is to be expected since this sample was collected $50 \mathrm{~cm}$ beneath sample Bln-5156. 
The end of period II and the end of the Ma'layba settlement is unclear but may antedate the appearance of solid architecture in Sabir not later than the 12th century BC.

An important by-product is the corrected dating of the remains of irrigation channels to the beginning of the 2nd millennium BC down to about the 16th century BC. Both samples Bln-5152 and Bln-5153 provide a terminus ante quem for their operation.

The type-site Sabir, just $5 \mathrm{~km}$ west of Ma'layba, is a major urban centre and, by far, the largest ruin of the Sabir Culture. Several smaller elevations can be made out on the surface hardly exceeding 3 $\mathrm{m}$ and imperceptibly passing over into the alluvial plain. Excavation trenches, laid out in far distant locations, are rather extensive and mostly—although not exclusively—devoted to the top cultural deposits. Recently, dug wells, modern construction pits, and the deep soundings of Sabir $2 \mathrm{C}$ and Sabir 8A show that the depth of the anthropogenic layers is 5-6 $\mathrm{m}$ in average.

Two different kinds of architecture can be distinguished: the lower strata as well as what is presently considered the periphery of Sabir are marked by the postholes of hut-dwellings of a round, sometimes rectangular plan. Better detectable mudbrick constructions, farmsteads, and residential buildings cluster in central locations usually close to the surface. Especially worth mentioning is Sabir 5 - certainly a ritual or politico-economic infrasite center. This general picture is supplemented by sanctuaries and several workshop areas for manufacturing personal ornaments, bone tools, bronze melting, and ceramics production.

As obscure as the stratigraphic beginnings of the settlement are, so unclear is also its end: an extremely dense deflation pavement of potsherds on the surface originates perhaps from several occupation layers once overlying the mudbrick ruins. They may indicate a re-occupation just before the armies of successive South Arabian kingdoms campaigned into the Wadi Tuban Delta and established their rule certainly not later than the middle of the $1 \mathrm{st}$ mill. BC. No material traces of these early kingdoms have been recorded from Sabir and its immediate surroundings yet.

One of the smallest, although chronologically most important excavation trenches is that of Sabir 8A encircling a small square mudbrick building of $3.5 \times 3.5 \mathrm{~m}^{2}$. On its exterior a small deep sounding was started from the bottom end of the mudbrick wall producing a sequence of nine cultural layers as far down as $4.5 \mathrm{~m}$ below the surface. No further mudbrick structures could be traced but stratified pottery was found, as known already from both period II and late period I at Ma'layba. ${ }^{14} \mathrm{C}$ samples date the construction of the small building around the late 12th century BC.

Sabir 2 is an elevation mainly known for its unusually high quantity of broken vessels and potsherds. This includes also a very high amount of overfired fragments that can altogether be associated with a number of successive pottery kilns tested in sounding Sabir 2C. Without reaching virgin soil the nearby trenches of Sabir 2 pit $2\left(5{ }^{14} \mathrm{C}\right.$ samples $)$ and Sabir $2 \mathrm{~A}\left(5{ }^{14} \mathrm{C}\right.$ samples $)$ yielded evidence for layers both without recognizable architectural remains and strata with mudbrick foundations antedating, respectively accompanying the operation of the kilns and making a functional connection between the buildings and the pottery workshops very likely.

In itself, the series of ${ }^{14} \mathrm{C}$-datings is conclusive. Pottery production goes back to the 11 th/10th century $\mathrm{BC}$ and is apparently responsible for the fast accumulation of the refuse and the other cultural layers. The earliest deposits, unrelated to the pottery manufacture, date to the 14th or 13th century $\mathrm{BC}-$ a period roughly contemporary with period I and II at Ma'layba - the earliest mudbrick walls date to not earlier than the 12th century $\mathrm{BC}$ and the combustion of a related timber construction (Bln-4884) to the early 9th century BC. 
Sample LE-4941 coming from the topmost layer of pit $2,{ }^{4}$ requires a comment: its calibrated dating somewhere between the 8th and the 6th century BC (with a wide standard deviation) has only one parallel in Sabir, i.e. in sample Bln-4731 from building 2 in Sabir 5 (see below). Although an incidental deposition of sample LE-4941 cannot be excluded a priori (such as the campfire of a shepherd), it is more likely to be associated to a re-occupation of the site, the evidence of which has survived only in the form of the dense deflation pavement.

Sabir 5, the most extensive excavation trench in Sabir, comprises the foundations of a vast monumental mudbrick complex with clear signs of planning which emphasizes its representative, public function. Its high outer wall enclosed a trapezoidal precinct of more than $5000 \mathrm{~m}^{2}$ surface with two diametrically opposed entrances. During its occupation the compound underwent several major architectural alterations to which several sub-phases and associated occupation levels can be added. Of prime interest within the context of ${ }^{14} \mathrm{C}$ dating are the buildings 1,2 , and 3 (and their vast adjoining courtyards), the foundations of which can be considered contemporary with the construction of the enclosure wall. All of these were constructed on top of earlier deposits without architecture. The basic component of buildings 1 to 3 are hypostyles with two, respectively, three naves. The naves of buildings 1 and 2 were later transformed into small open courtyards. Buildings 1 and 2 are supplemented by several subsidiary rooms, building 3 by a forecourt.

Nine samples come from Sabir 5 that is stratigraphically associated with the earliest occupation (Bln-4888), the transformation into small internal courtyards (Bln-4730), the overlying occupations (Bln-4727-4729), and the final destruction of building 3 (Bln-4889-4891).

Within this series from Sabir 5, sample Bln-4731 with a date from the 9th century BC is clearly too young especially when compared to its stratigraphic position. Although a disturbance in the building's 2 kitchen annex has not been recorded during excavation, this ${ }^{14} \mathrm{C}$ date can be considered uncontaminated and therefore reliable. The sample may, in fact, originate from one of those numerous pits dug into the top debris layer after a major destruction, ruining, and temporary abandonment of the Sabir 5 area. It may reflect the same re-occupation of the site as already suggested through the 8th to 6th century BC sample LE-4941 from Sabir 2.

The earliest occupation of Sabir 5 buildings 1 and 2 can reliably be dated to around the 12th century $\mathrm{BC}$ - a date that, with reference to architectural observations, can be applied also to building 3 and the entire trapezoidal enclosure wall. While there is evidence that a final occupation of the two buildings dates probably from the early 10 th century $\mathrm{BC}$, building 3 obviously attests to a different and later end: much care was invested in the regular layout of the building that with its forecourt and lateral court galleries somehow recalls the plan of South Arabian temples. The building's inventory, mainly pottery, is largely different from that of all other contemporary structures underlining its outstanding significance. Archaeologically, it is also important for a couple of other findings: A brick red color of the walls and a thick layer of mudbrick debris all over the place attest a heavy conflagration (see Bln4889). The attached store, fully packed with empty vessels and many others still containing plenty of botanical remains (Bln-4891), was buried directly under carbonized mat weaving and burnt timber. Behind the central platform of the forecourt a human skeleton was discovered, documenting the fate of an individual apparently killed by the collapsing and burning roof (Bln-4890). These three samples overlap chronologically near the end of the 10th century BC, giving testimony of a violent end.

${ }^{4}$ The two samples LE-4940: $3040 \pm 40$ BP and LE-4941: $2520 \pm 100$ BP, originally marked with the cyrillic letters LE (= Leningrad), were kindly processed in the St Petersburg Radiocarbon Laboratory, Russia. We are grateful for the permission to publish these dates here. 


\section{CONCLUSIONS}

With the results of the German-Russian field work in the Lahj Governorate and beyond the Hadramawt and Ramlat as-Sab'atayn desert belt, the westerly coastal plains have entered the scene as the third major cultural province of Ancient Southwest Arabia (Vogt 1998, 2000; Vogt and Sedov 1998, 2000). This applies both to the prehistoric and the proto-historic periods.

The Sabir Culture, represented here by the sites of Ma'layba and Sabir, is rooted in a Bronze Age tradition that continues well into later periods. Manifesting itself in monumental mudbrick architecture, developed centralized political structures, and sophisticated irrigation schemes, the culture reaches its final though short climax basically just before its disappearance, i.e. by about the 12th century BC. Elsewhere in the Ancient Near East this is the period of an advanced Early Iron Age.

Evaluating the ${ }^{14} \mathrm{C}$ sequence, the end may not have been as fast and sudden as previously assumed. Conflagrations were a frequent phenomenon but even the major destruction (of Sabir 5 building 3) by about the late 10th century was certainly not the ultimate end. Sabir did definitely not recover but somehow agonized for several more generations. Unproven by archaeological evidence, although not unlikely, the end came perhaps through the hands of the Sabaeans (by about 700 BC) or slightly later with the establishment of the rule of the kingdom of Qataban.

\section{ACKNOWLEDGMENTS}

The surveys and excavations in the Lahj Governorate are a project carried out by the German Archaeological Institute, Sanaa, and the Russian Academy of Sciences, Moscow, under the joint direction of Burkhard Vogt and Aleksandr Sedov. Field work would have been impossible without the support of the Yemeni General Organization of Antiquities, Museums, and Manuscripts, its chairman, Prof Dr Yussuf Abdullah and its Lahj representative Mr. Musleh Ali Ahmad al-Qubati in particular. Special thanks go to all our colleagues who devoted much of their time and energy to the progress of the project throughout the years. We are especially obliged to Vittoria Buffa for directing the field work at Ma'layba and for her basic research both on the stratigraphy and the pottery sequence of Ma'layba. We gratefully acknowledge Dr H Erlenkeuser and colleagues (LeibnizLabor, University of Kiel) for $\delta^{13} \mathrm{C}$ measurements. Thanks are also extended to E Lau and D Teckenburg for assistance in the preparation and measurement of samples.

\section{REFERENCES}

Görsdorf J. 1990. Die Interpretation von ${ }^{14} \mathrm{C}$-Datierungen im Berliner ${ }^{14} \mathrm{C}$-Labor. Zeitschrift für Archäologie 24:27-34 (in German).

Görsdorf J, Bojadziev J. 1996. Zur absoluten Chronologie der bulgarischen Urgeschichte. Berliner ${ }^{14} \mathrm{C}$-Datierungen von bulgarischen archäologischen Fundplätzen. Eurasia Antiqua 2:105-73. In German.

Görsdorf J. 2000. Datierungen im Berliner ${ }^{14} \mathrm{C}$-Labor. Berliner Beiträge zur Archäometrie 17:121-31. In German.

Mook W G, Streurman H J. 1983. Physical and chemical aspects of radiocarbon dating. Journal of the European Study Group on Physical, Chemical and Mathematical Techniques Applied to Archaeology. PACT 8: 31-55.

Ramsey CB. 1995. Radiocarbon calibration and analysis of stratigraphy: OxCal Program. Radiocarbon 37(2):
425-30.

Ramsey CB. 2000. Internet version of the OxCal Program v.3.5. (www.rlaha.ox.ac.uk/orau/06_01.htm).

Stuiver M, Reimer PJ, Bard E, Beck JW, Burr GS, Hughen KA, Kromer B, McCormac FG, van der Plicht J, Spurk M. 1998. INTCAL98 radiocarbon age calibration 24,000-0 cal BP. Radiocarbon 40(3):104183.

Vogt B. 1998. Frühe Kulturen an der Küste des Roten Meeres und des Golfs von Aden. In: Jemen-Kunst und Archäologie im Land der Königin von Saba. Vienna: Exhibition Catalogue, Kunsthistorisches $\mathrm{Mu}-$ seum Wien. p.122-27 (in German).

Vogt B, Sedov A. 1998. The Sabir culture and coastal Yemen during the second millennium $\mathrm{BC}$ - the present state of discussion. Proceedings of the Seminar for Arabian Studies 28:261-70. 
Vogt B, Sedov A. 1998. Die Sabir-Kultur und die jemenitische Küstenebene in der 2. hälfte des 2. Jahrtausends v. Chr. In: Jemen-Kunst und Archäologie im Land der Königin von Saba. Vienna: Exhibition Catalogue, Kunsthistorisches Museum. 129-33, cat. no.77-130.
Vogt B. 2000. Begraben und vergessen-Sabir, eine Stadt des späten 2. Jts. v. Chr. am Golf von Aden/Jemen. In: Deutsches Archäologisches Institut. Archäologische Entdeckungen. Die Forschungen des Deutschen Archäologischen Instituts im 20. Jahrhundert. Mainz: Antike Welt Sonderheft:44-9. 